\title{
PENGARUH RESIN TERHADAP PERUBAHAN WARNA PADA CAT TEMBOK
}

\author{
Nurlela* dan Risnawati \\ Program Studi Kimia FMIPA Universitas Nusa Bangsa Bogor \\ Jl. KH Sholeh Iskandar KM 4 Tanah Sareal, Bogor 16166 \\ *e-mail: nnurlela16@gmail.com
}

\section{ABSTRACT \\ The Influence of Resin against the Change of Color on the Wall Paint}

\begin{abstract}
The quality of the paint is determined by the resin used. Synthetic resins for polymer paints are made by combining several monomers to achieve various characteristics. The incorporation of some monomers such as polyvinyl acetate resin, acrylic vinyl resin and acrylic styrene resin which act as a binder can affect the quality of the paint especially the color change. The purpose of this study is to find the color changes that occur on the wall paint by using Poly Styrene Acrylic, Poly Vinyl Acetate and Poly Vinyl Acrylic. From the results of the measurement of color difference, significant color change occurs in the Poly Vinyl Acetate (PVAc) + Poly Vinyl Acrylic (PVA) and Poly Styrene Acrylic (PSA). The results of the quality test of the three resins based on pH test, scrub test and viscosity test, PSA has better quality compared to PVA + PVAc and PVA resin. From the color difference measurement test, some things need to be considered, are temperature, film thickness, substrate color/background color and measurement conditions (measured in wet sample/in plate/dry surface) and test on resin added additive according to the type of each resin.
\end{abstract}

Keywords: Paint, Resin, Color Changes, Poly Vinyl Acetate, Poly Styrene.

\begin{abstract}
ABSTRAK
Kualitas dari cat sangat ditentukan oleh resin yang digunakan. Resin sintetis untuk cat berupa polimer yang dibuat dengan menggabung beberapa monomer untuk mencapai berbagai karakteristik. Penggabungan dari beberapa monomer seperti resin poli vinil asetat, resin vinil akrilik dan resin stirena akrilik yang berfungsi sebagai pengikat mampu mempengaruhi kualitas cat terutama dari perubahan warna. Tujuan dari penelitian ini adalah untuk mengetahui perubahan warna yang terjadi pada cat tembok dengan menggunakan Poli Stirena Akrilik, Poli Vinil asetat dan Poli Vinil Akrilik. Dari hasil pengukuran perbedaan warna, perubahan warna cukup signifikan terjadi pada resin Poli vinil Asetat (PVAc) + Poli Vinil Akrilik (PVA) dan resin Poli Stirena Akrilik (PSA). Hasil uji Kualitas cat dari ketiga resin berdasarkan uji $\mathrm{pH}$, uji scrub dan uji viscositas, PSA memiliki kualitas yang lebih baik dibandingkan dengan resin PVA+PVAc dan PVA. Dari pengujian pengukuran perbedaan warna, beberapa hal yang perlu di perhatikan, yaitu suhu, film thickness, warna substrat/background color dan kondisi pengukuran (diukur dalam keadaan wet sample/dalam bentuk plateldry surface) dan pengujian terhadap resin yang ditambahkan zat aditif yang sesuai dengan tipe masing-masing resin tersebut.
\end{abstract}

Kata Kunci: Cat, Resin, Perubahan Warna, Poli Vinil, Poli Stirena.

\section{PENDAHULUAN}

Industri cat adalah salah satu industri tertua di dunia. Cat adalah suatu cairan yang di pakai untuk melapisi suatu bahan dengan tujuan memperindah, memperkuat dan melindungi bahan tersebut. Setelah dikenakan pada permukaan dan mengering, cat akan membentuk lapisan tipis yang melekat kuat dan padat pada permukaan tersebut. Semakin berkembangnya pembangunan di indonesia, menyebabkan semakin tingginya permintaan konsumen terhadap cat baik cat tembok (water base) maupun cat minyak (solvent base).

Tingginya permintaan konsumen terhadap permintaan cat tembok maupun cat minyak, membawa dampak yang positif untuk para industri cat. Hal ini dikarenakan setiap bangunan membutuhkan cat untuk melapisi tembok atau dindingnya untuk memberi kesan bersih dan meningkatkan penampilan visualnya. Dengan semakin banyaknya proyek-proyek pemerintah untuk membangun rumah bersubsidi bagi masyarakat yang kurang mampu, 
menginspirasi pengusaha industri cat untuk menciptakan produk cat yang berkualitas dengan harga ekonomis. Pembuatan cat yang berkualitas dengan harga ekonomis juga ditujukan untuk konsumen yang hobi mengganti warna pada dinding/tembok pada bangunannya dan semua kalangan masyarakat mempunyai daya beli terhadap cat tersebut sehingga mereka dapat berkreasi terhadap setiap sisi bangunannya tanpa mengeluarkan pengeluaran yang besar.

Kualitas dari cat sangat ditentukan oleh resin yang digunakan dalam prosesnya dengan memanfaatkan teknologi kimia organik dan kimia polimer. Rancangan polimer untuk cat berupa komposit dengan persyaratan tinggi untuk mencapai berbagai fungsi, sebagai aplikasi utama dari kimia polimer. Resin sintetis untuk cat berupa polimer yang dibuat dengan menggabung beberapa monomer untuk mencapai berbagai karakteristik. Penggabungan dari beberapa monomer seperti resin poli vinil asetat, resin vinil akrilik dan resin stirena akrilik yang berfungsi sebagai pengikat mampu mempengaruhi kualitas cat terutama dari perubahan warna (wiley,1997). Tujuan dari penelitian ini adalah untuk mengetahui perubahan warna yang terjadi pada cat tembok dengan menggunakan resin Stirena Akrilik, Poli Vinil asetat dan Poli Vinil Akrilik.

\section{BAHAN DAN METODE}

\section{Bahan dan Alat}

Bahan yang digunakan yaitu cat Tembok NB dengan mensubtitusi pemakaian resin sebanyak $6 \%$ ke dalam formula:

1. Cat tembok NB menggunakan resin Poli Vinil Akrilik (PVA)+Resin PoliVinil Asetat (PVAc).

2. Cat Tembok NB menggunakan resin Poli Vinil Akrilik (PVA).

Cat Tembok NB menggunakan resin Poli Stirena Akrilik ( PSA).

Peralatan yang digunakan yaitu $\mathrm{pH}$ meter, viscometer brokfield, spesific gravity (SG) cup, timbangan digital, spectrum datacolor 110, scrubmeter biuged.

\section{Metode}

\section{Uji pH}

Cat yang ada dalam wadah di ukur pada suhu $25^{\circ} \mathrm{C}$ dengan menggunakan alat $\mathrm{pH}$ meter. Hasil yang tertera pada layar di catat.

\section{Uji Viscositas}

Cat dimasukkan kedalam wadah. Pada suhu $25^{\circ} \mathrm{C}$ diukur dengan alat viscometer brokfied. Hasil yang tertera pada layar di catat.

\section{Uji Densitas}

SG cup ditimbang kosong terlebih dahulu $\left(\mathrm{w}_{0}\right)$. Cat dimasukkan kedalam SG cup sampai melewati batas garis dan di tutup rapat. Cat yang keluar pada tutup SG cup dibersihkan dan di timbang $\left(\mathrm{w}_{1}\right)$.

Perhitungan:

$$
\text { Densitas }=\frac{\mathrm{W} 1-\mathrm{W} 0}{\text { Volume Sampel }}
$$

\section{Uji Perbedaan Warna \\ Prosedur alat}

Komputer dinyalakan. Spectrum datacolor 110 dinyalakan dengan menekan display yang ada di belakang dan dibiarkan hingga 30 menit. Pada desktop "DATACOLOR TOOLS PLUS" diklik 2x. Kemudian dilakukan kalibrasi alat. Kalibrasi di lakukan 4 jam sekali (tergantung intensitas pemakaian alat, jika jarang digunakan cukup kalibrasi di lakukan 8 jam sekali).

\section{Prosedur pengerjaan sampel}

Cat ditarik pada kertas film menggunakan aplikator yang berukuran 120 $\mu$ pada saat pemeriksaan standar. Usahakan tarikan sehalus mungkin dan dengan ketebalan yang sama sehingga hasil yang terbaca tidak menyimpang. Di keringkan pada oven pada suhu $100{ }^{\circ} \mathrm{C}$, dan diperiksa setelah suhu tarikan sudah dingin.

\section{Uji Scrub \\ Prosedur alat}

Wadah diisi dengan air bersih untuk air yang nantinya akan di pompa ke wadah panel. Alat dinyalakan dengan menekan 
tombol Power. Tombol "SET" ditekan untuk menentukan jumlah cycle yang dibutuhkan. Tombol “ $\longleftarrow$ " ditekan untuk 0000 dan “ $\rightarrow$ " untuk 00. Tombol "个" ditekan untuk menaikkan angka cycle (putaran) dan " $\downarrow$ " untuk menurunkan angka cycle (putaran). Tombol "speed" diputar untuk mengatur kecepatan putaran. Standar yang digunakan 27 rpm. Tombol "start" ditekan untuk memulai menjalankan putaran. Diamati perubahan yang terjadi.

\section{Prosedur pengerjaan sampel}

Cat ditarik pada plat asbes menggunakan aplikator berukuran $120 \mu$. Dikeringkan pada suhu ruang selama 7 hari. Kemudian diperiksa pada alat Wet Abrasion Scrub Tester.

\section{HASIL DAN PEMBAHASAN}

Berikut data hasil uji $\mathrm{pH}$, uji viscositas, uji densitas, uji perbedaan warna dan uji scrub.

\section{Uji pH}

Uji pH dengan standar kualitas SNI sebesar 7-9,5. Hasil pengujian $\mathrm{pH}$ dimaksudkan agar cat aman pada saat digunakan bila terkena bagian tubuh serta sebagai media untuk mempertahankan fungsi dari anti bakteri.

Penggunaan resin stirena Akrilik (PSA) lebih stabil dibandingkan dengan penggunaan resin PVA+PVAC dan PVA. Hal ini dipengaruhi dari $\mathrm{pH}$ awal dari masing-masing resin itu sendiri. Resin PSA memiliki pH antara 7-8, Resin PVA dan PVAC memiliki pH antara 3-5. Hasil pengujian $\mathrm{pH}$ dapat dilihat pada Tabel 1 .

\section{Uji Viscositas}

Uji viskositas atau kekentalan dengan standar kualitas SNI minimal sebesar 90 KU. Pengujian kekentalan pada penelitian ini dilakukan dengan menggunakan alat ukur viskositas Brookfield.

Hasil pengujian viskositas dapat dilihat pada Tabel 2. Sampel cat dengan resin PVA+PVAc memiliki peningkatan viskositas yang jauh signifikan.

Hal ini disebabkan karena resin PVA+PVAc mempunyai penambahan Filler pada resin itu sendiri sehingga pada proses penyimpanan akan mengalami kenaikan viscositas yang jauh signifikan di bandingkan dengan Poli Stirena Akrilik (PSA). Hasil tersebut memenuhi Standar Nasional Indonesia (SNI), akan tetapi cat yang memiliki kekentalan yang tinggi dapat mempengaruhi konsumen untuk menambahkan pelarut yang berlebihan pada saat aplikasi. Penambahan pelarut yang berlebihan pada cat yang mempunyai konsentrasi resin dibawah $10 \%$ akan membuat fungsi dari resin tersebut menurun dalam mengikat pigmen utama dan pigmen extender sehingga cat tersebut setelah di aplikasi menjadi berkapur (chalking).

Tabel 1. Hasil Pengetesan pH Menggunakan Resin Poli Vinil Akrilik(PVA) +Poli Vinil Acetat(PVAc), Poli Vinil Akrilik(PVA) dan Poli Sterina Akrilik(PSA).

\begin{tabular}{cccc}
\hline Pengujian $\mathrm{pH}$ & PVA+PVAC & PVA & PSA \\
\hline Hari ke 1 & 8,67 & 8,71 & 9,05 \\
Hari ke 2 & 8,48 & 8,69 & 8,81 \\
Hari ke 7 & 8,47 & 8,53 & 8,76 \\
Hari ke 14 & 8,36 & 8,52 & 8,75 \\
Hari ke 28 & 8,21 & 8,39 & 8,69 \\
Hari ke 42 & 8,08 & 8,36 & 8,69 \\
Hari ke 56 & 8,07 & 8,19 & 8,64 \\
\hline
\end{tabular}


Tabel 2. Hasil Pengetesan Viscositas Menggunakan Resin Poli Vinil Akrilik (PVA)+Poli Vinil Acetat(PVAc), Poli Vinil Akrilik(PVA) dan Poli Sterin Akrilik(PSA) dalam Satuan Krebs Unit (KU).

\begin{tabular}{cccc}
\hline Pengujian & & & \\
Viscositas & PVA+PVAc(KU) & PVA(KU) & PSA(KU) \\
\hline Hari ke 1 & 96,3 & 95,1 & 97,1 \\
Hari ke 2 & 112,7 & 102,1 & 101,6 \\
Hari ke 7 & 114,1 & 110,2 & 101,3 \\
Hari ke 14 & 114,8 & 110,8 & 102,3 \\
Hari ke 28 & 115,5 & 110,7 & 102,1 \\
Hari ke 42 & 115,3 & 110,9 & 102,7 \\
Hari ke 56 & 115,6 & 112,6 & 102,2 \\
\hline
\end{tabular}

\section{Uji Densitas}

Penentuan densitas masing-masing sampel berpengaruh pada hiding power atau daya tutup cat pada saat diaplikasikan pada media. Standar kualitas dari SNI minimal $1,2 \mathrm{~g} / \mathrm{mL}$

Perbedaan densitas tidak jauh signifikan diantara ketiga resin tersebut karena didalam formulasi jumlah filler yang digunakan sama. Perbedaan densitas di pengaruhi dari resin PVA+PVAc yang didalam formulasinya sudah terdapat Filler (bahan pengisi). Hasil pengujian densitas dapat dilihat pada Tabel 3.

\section{Uji Perbedaan Warna}

Warna merupakan bagian utama dari Cat. Kestabilan dan akurasi warna dapat dipengaruhi oleh Resin yang digunakan dengan bahan aditif lainnya. Perbedaan warna yang cukup signifikan terjadi pada cat dengan penggunaan Resin Poli Vinil Akrilik (PVA) + Resin Poli Vinil Asetat (PVAc). Hal ini terjadi karena sifat dari polivinil asetat yang mempunyai ikatan rangkap $\mathrm{C}=\mathrm{O}$ yang bersifat tidak stabil. Hasil pengujian perbedaan warna dapat dilihat pada Tabel 4.

Perubahan warna yang terjadi pada cat menggunakan resin Poli Stirena Akrilik disebabkan karena pada produk terdapat pendan benzen yang mempengaruhi kestabilan produk sehingga mudah teroksidasi dan juga adanya ikatan $\mathrm{C}=\mathrm{O}$.

Perubahan Warna yang terjadi pada cat yang menggunakan Resin PoliVinil Akrilik (PVA) tidak jauh signifikan. Hal ini disebabkan panjang pendan dari Vinil Akrilik yang berbentuk rantai lurus dan ikatan jenuh sehingga tidak mudah teroksidasi oleh udara maupun radikal bebas.

Tabel 3. Hasil Pengujian Densitas Menggunakan Resin Poli Vinil Akrilik+Poli Vinil Acetat, Poli Vinil Akrilik dan Poli Sterin Akrilik

\begin{tabular}{cc}
\hline Resin & Densitas $(\mathrm{g} / \mathrm{mL})$ \\
\hline PVA+PVAC & 1,62 \\
PVA & 1,62 \\
PSA & 1,61 \\
\hline
\end{tabular}


Tabel 4. Hasil pengetesan Densitas menggunakan resin Poli Vinil Akrilik(PVA) +Poli Vinil Acetat(PVAc), Poli Vinil Akrilik (PVA) dan Poli Sterin Akrilik(PSA).

\begin{tabular}{cccc}
\hline Uji Perbedaan warna (DE*) & PVA+PVAC & PVA & PSA \\
\hline Hari ke 2 & 0,33 & 0,32 & 0,36 \\
Hari ke 7 & 0,52 & 0,39 & 0,44 \\
Hari ke 14 & 0,65 & 0,40 & 0,52 \\
Hari ke 28 & 0,80 & 0,42 & 0,62 \\
Hari ke 56 & 0,87 & 0,45 & 0,87 \\
\hline
\end{tabular}

\section{Uji Scrub}

Penentuan uji scrub masing-masing resin berpengaruh pada kekuatan film cat setelah di aplikasikan pada suatu media. Dari ketiga resin, resin Poli Stirena Akrilik mempunyai hasil scrub yang paling tinggi sehingga kualitas film yang terbentuk dari resin PSA memiliki kualitas film yang paling baik dibandingkan resin PVAc+PVA dan PVA. Hal ini disebabkan oleh pendan benzen yang terdapat pada stirena akrilik yang menyebabkan Temperatur Glasses (Tg) dari resin poli stirena akrilik tinggi. Semakin tinggi $\mathrm{Tg}$ maka semakin keras suatu monomer maupun polimer tersebut.

Tabel 5. Hasil Uji Scrub menggunakan resin Poli Vinil Akrilik +Poli Vinil Acetat, Poli Vinil Akrilik dan Poli Stirena Akrilik

\begin{tabular}{cc}
\hline Resin & Cycle \\
\hline PVA+PVAC & 25 \\
PVA & 31 \\
PSA & 48 \\
\hline
\end{tabular}

\section{KESIMPULAN}

Dari hasil pengukuran perbedaan warna, perubahan warna cukup signifikan terjadi pada resin Poli vinil Asetat (PVAc) + Poli Vinil Akrilik (PVA) dan resin Poli Stirena Akrilik (PSA). Hasil uji Kualitas cat dari ketiga resin berdasarkan uji $\mathrm{pH}$, uji scrub dan uji viscositas, PSA memiliki kualitas yang lebih baik dibandingkan dengan resin PVA+PVAc dan PVA. Pengujian pengukuran perbedaan warna beberapa hal yang perlu di perhatikan suhu, film thickness, warna substrat/background color dan kondisi pengukuran (diukur dalam keadaan wet sample/dalam bentuk plate/Dry surface) serta perlunya dilakukan pengujian resin ditambah dengan zat aditif yang sesuai dengan tipe masing-masing resin tersebut.

\section{DAFTAR PUSTAKA}

Hamburg, H.R. dan Morgans, W.M. Tanpa Tahun. Hess's Paint Film Defects. Edisi III. London: Chaman and Hall

Lambourne, R. 1987. Paint and Surface Coating. New York : Ellis Horwood Limited

Malik, I. 2009. Cat Tembok. Diakses pada: http://iwanmalik.wordpress.com/200 9/07/29/cat-tembok-bliz/

Marcus, Robert T. 1999. Colorimetry. Crc Press Llc

Stevens, Malcom P. Penerjemah: Iis Sopyan. 2007. Kimia Polimer. Jakarta : Pradnya paramita

SNI 3564 : 2009 Cat Tembok Emulsi.

Tracton, Arthur A.. 2007. Coating Materials and Surface Coatings. Taylor dan Francis Group

Waldie, J. M. 1983. Surface Coating. Volume I. Australia : Oil dan Colour Chemists' Association

Wiley, J. 1997. Waterborne \& Solvent Based Acrylic and their End User Applications. London : Sita Technology Limited 